\title{
Synthesis of Strontium-Graphite Intercalation Compounds
}

\author{
N. Akuzawa*, M.Ogima*, T. Amemiya* and Y. Takahashi** \\ * Tokyo National College of Technology, Hachioji-shi, Tokyo 193, Japan \\ ** Nuclear Engineering Research Laboratory, Faculty of Engineering, \\ University of Tokyo, Tokai-mura, Ibaraki 319-11, Japan
}

(Received 11 Oct., 1984)

\begin{abstract}
Conditions for obtaining the stage $1 \mathrm{Sr}$-GIC from natural graphite flake, Grafoil and artificial graphite (petroleum coke HTT $2600^{\circ} \mathrm{C}$ ) by a convenient two-bulb technique were determined. The stage $1 \mathrm{Sr}$-GIC was isolated for natural graphite flake and the identity period and chemical composition were determined to be $4.95 \AA$ and $\mathrm{SrC}_{6}$, respectively in accordance with those reported by Guerard et al.

Temperature favorable to obtain the stage 1 Sr-GIC was found to be in the region between $460^{\circ} \mathrm{C}$ and $490^{\circ} \mathrm{C}$, although reaction period also should be controlled because the stage $1 \mathrm{Sr}$-GIC was not the final product but an intermediate one toward the carbide.

Grafoil and artificial graphite also gave the stage 1 Sr-GIC, but the isolation was not performed.

The stage 1 Sr-GIC was found to be very stable in the air. Even after 6 days of exposure to the air at $120^{\circ} \mathrm{C}$, it was not fully decomposed but a large part remained in the residue.
\end{abstract}

\section{INTRODUCTION}

Researches on the synthesis of strontiumgraphite intercalation compound (Sr-GIC) have been reported by Guerard et al. ${ }^{1), 2)}$ Their results are summarized as follows; (1) Sr-GIC can be prepared by both the usual two-bulb technique and the solid phase reaction of the mixed powder of metallic strontium and graphite. (2) By the usual two-bulb technique, only the stage 1 Sr-GIC was obtained from natural graphite or PGCCL (Le Carbone Lorraine). (3) By the solid phase reaction, Sr-GICs of stage 1 to stage 6 were formed, although those of stage 2 to stage 6 were always mixed and were not isolated. (4) The identity period of the stage $1 \mathrm{Sr}$-GIC was $4.94 \AA$ with the c-axis parameter of $9.88 \AA$ and the chemical composition was determined to be $\mathrm{SrC}_{6}$.

This study presents detailed conditions for the preparation of Sr-GICs from natural graphite, artificial graphite and Grafoil.

\section{EXPERIMENTAL}

\subsection{Materials}

Graphite samples used were natural graphite flake (mean particle size: $220 \mu \mathrm{m}$ ), Grafoil GTA (Union Carbide Co. Ltd., the planar sample with the size of $10 \mathrm{~mm} \times 30 \mathrm{~mm} \times 0.4 \mathrm{~mm})$ and artificial graphite (petroleum coke HTT $2600^{\circ} \mathrm{C}$ ). These graphite samples were heated in a vycor glass tube at around $1000^{\circ} \mathrm{C}$ under vacuum of $0.1 \mathrm{mPa}$ before the preparation procedures.

Strontium metal (Nakarai Kagaku Co. Ltd.) with the purity of $99 \%$, was washed with ether to remove oils adhering to the surface and was used for the experiment without further purification.

\subsection{Preparation procedure}

A vycor glass ampoule was used for the preparation, which is shown in Fig. 1. An appropriate amount of metallic strontium was placed in a steel tube to prevent the corrosion of vycor glass by the molten strontium. The ampoule was sealed under vacuum of $0.1 \mathrm{mPa}$, and then heated by a gas burner until the evolution of the strontium vapor was recognized. Then the graphite sample was 


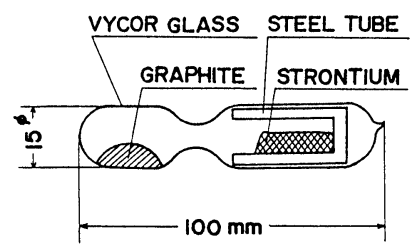

Fig. 1 Vycor glass ampoule for the preparation of Sr-GIC.

maintained at a fixed temperature between 350 and $600^{\circ} \mathrm{C}$ in an electric furnace, while strontium was held at a slightly lower temperature. They were kept at these temperatures for periods from 1 hour to 2 weeks.

\subsection{Identification of the reaction products}

The X-ray diffraction measurement by $\mathrm{Cu} \mathrm{K} \alpha$ was used to determine the extent of the reaction and the stage structure of the product obtained.

Chemical analysis was performed using the apparatus shown in Fig. 2. The sample of reaction product was weighed and put into a vycor boat, which was then placed in a combustion tube held at about $850^{\circ} \mathrm{C}$. By the combustion of the sample under oxygen gas flow, carbon was changed to $\mathrm{CO}_{2}$ and strontium remained in the residue. Evolved $\mathrm{CO}_{2}$ gas was collected by an ascarite tube and its weight change was measured, while the residue on the boat was dissolved in diluted hydrochloric acid, and the strontium content of the solution was determined by the flame spectrochemical analysis.

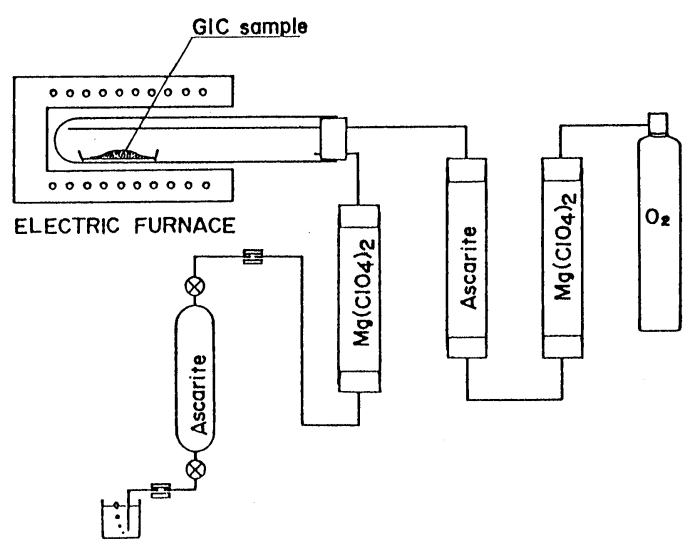

Fig. 2 Apparatus for the chemical analysis of Sr-GICs.

\section{RESULTS AND DISCUSSION}

\subsection{Preparation of Sr-GICs from natural graphite} flake

The X-ray diffraction diagram of the shiny golden product obtained by the reaction at $470^{\circ} \mathrm{C}$ for 6 days is shown in Fig. 3. It is seen that the compound was almost single phase and as shown in Table 1 , the identity period was determined as $4.95 \AA$, which is in good agreement with the value of the stage 1 Sr-GIC reported by Guerard et al. ${ }^{1}$. The lines due to the superlattice structure of AaAbAa... also reported by them ${ }^{2}$ ) can be found in the figure.

The results of chemical analysis of the sample stated above are shown in Table 2. It can be said that this sample has the chemical composition of $\mathrm{SrC}_{6}$, although the values are somewhat scattered. The composition determined in the present study agrees well with that reported by Guerard et al. ${ }^{2}$ ) They obtained the value from the determination of the volume of the hydrogen evolved by the action of water on the Sr-GIC and from the acidi-

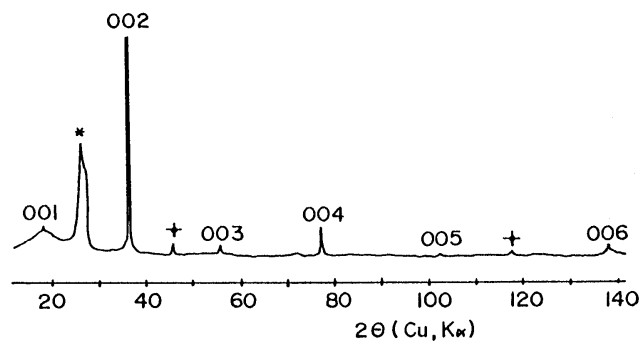

Fig. 3 X-ray diffraction diagram of the isolated stage 1 Sr-GIC from natural graphite flake.

*, Peak due to the film with which the sample is covered;

+ , Peaks due to superlattice structure.

Table 1 Observed d-spacings and identity period for stage $1 \mathrm{Sr}-\mathrm{GIC}$.

\begin{tabular}{ccc}
\hline $00 l$ & $\mathrm{~d} / \AA$ & $\mathrm{I}_{\mathrm{c}} / \AA$ \\
\hline 001 & 4.951 & 4.95 \\
002 & 2.466 & 4.93 \\
003 & 1.646 & 4.94 \\
004 & 1.236 & 4.94 \\
005 & 0.900 & 4.95 \\
006 & 0.825 & 4.95 \\
\hline
\end{tabular}


Table 2 Results of chemical analysis of stage 1 Sr-GIC.

\begin{tabular}{ccccc}
\hline Run No. & Sr-GIC/mg & Carbon content $/ \mathrm{mg}$ & Sr content $/ \mathrm{mg}$ & $\mathrm{C} / \mathrm{Sr}$ \\
\hline 1 & 12.9 & 6.03 & 6.88 & 6.40 \\
2 & 21.0 & 9.10 & 11.90 & 5.58 \\
3 & 21.5 & 9.65 & 11.85 & 5.95 \\
\hline
\end{tabular}

Table 3 Calculated and observed relative peak intensity ratio for stage 1 Sr-GIC.

\begin{tabular}{ccc}
\hline $00 l$ & $\mathrm{I}_{\text {calculated }}$ & $\mathrm{I}_{\text {observed }}$ \\
\hline 001 & 3.1 & 0.8 \\
002 & 100 & 100 \\
003 & 1.5 & 1.4 \\
004 & 8.2 & 8.2 \\
005 & 0.5 & 0.3 \\
006 & 7.0 & 4.9 \\
\hline
\end{tabular}

metry on the resulting solution, while our data were derived from the direct chemical analysis of strontium and carbon after the combustion of the sample. Recent investigations ${ }^{3), 4), 5)}$ on the reaction of K-GIC with water show that sometimes not all potassium are extracted from the K-GIC, but a fairly large amount of potassium remained in the residue. Therefore the combustion method seems more appropriate in the analysis of GICs. The agreement of the both results suggests that in the experiment of Guerard et al. ${ }^{2)}$ the dissolution of strontium from $\mathrm{Sr}$-GIC into water was perfectly completed, thus the composition of $\mathrm{SrC}_{6}$ for the stage $1 \mathrm{Sr}-\mathrm{GIC}$ seems to be confirmed.

The observed and calculated X-ray diffraction peak intensity ratios are given in Table 3. The calculated values were derived by using the composition of stage $1 \mathrm{Sr}-\mathrm{GIC}$ to be $\mathrm{SrC}_{6}$. Satisfactory agreement is obtained between the two.

At temperatures higher than $500^{\circ} \mathrm{C}$, the formation of carbide was recognized, while at temperatures lower than $450^{\circ} \mathrm{C}$, the reaction was very slow. Even at $460-490^{\circ} \mathrm{C}$, it seems that the stage 1 Sr-GIC is not the final product but the intermediate one in the course of the carbide formation. Therefore in order to isolate the stage 1 Sr-GIC, not only temperature but also reaction period must be precisely controlled.

\subsection{Preparation of Sr-GICs from Grafoil}

A typical X-ray diffraction diagram of the resultant sample which was prepared from a sheet

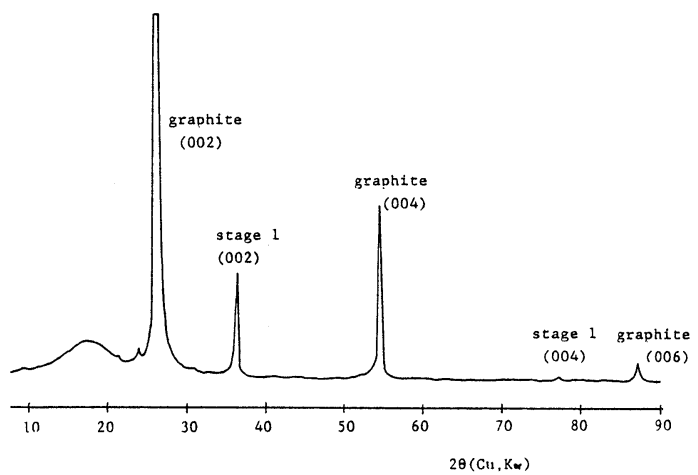

Fig. 4 Typical X-ray diffraction diagram of Sr-GIC from Grafoil.

of Grafoil under the conditions of $450^{\circ} \mathrm{C}, 49.5 \mathrm{~h}$, is shown in Fig. 4. The strong $(00 l)$ peaks of graphite are seen in addition to the (002) line of stage $1 \mathrm{Sr}$-GIC, although the appearance of the sample is shiny golden. This figure was essentially not changed even if the reaction period was prolonged. From the observation of the sectional plane of a planar sample it was found that the peripheral part was shiny golden, while the inner part was still black, indicating that the diffusion rate of strontium toward inner region is very slow. No carbide peak was observed at this reaction temperature.

By raising the reaction temperature higher than $450^{\circ} \mathrm{C}$, a small peak at $30.9^{\circ}$ due to $(200)$ plane of carbide $\left(\mathrm{SrC}_{2}\right.$ in a tetragonal system) became appeared. This effect of reaction temperature on the reaction products is shown in Fig. 5, where the ordinate is the relative peak intensity ratios defined as:

$$
\mathrm{I}_{\mathrm{SrC}_{6}(002)} /\left[\mathrm{I}_{\mathrm{SrC}_{6}(002)}+\mathrm{I}_{\mathrm{gr} .(004)}+\mathrm{I}_{\mathrm{SrC}_{2}(200)}\right] \text {, }
$$
or,

$\mathrm{I}_{\mathrm{SrC}_{2}(\mathbf{2 0 0 )})} /\left[\mathrm{I}_{\mathrm{SrC}_{6}(\mathbf{0 0 2 )}}+\mathrm{I}_{\mathrm{gr} .(004)}+\mathrm{I}_{\mathrm{SrC}_{2}(200)}\right]$, and the abscissa is the reaction temperature. On the assumption that the relative peak intensity thus defined indicates the extent of the reaction, it is followed that below $500^{\circ} \mathrm{C}$ a mixture of 


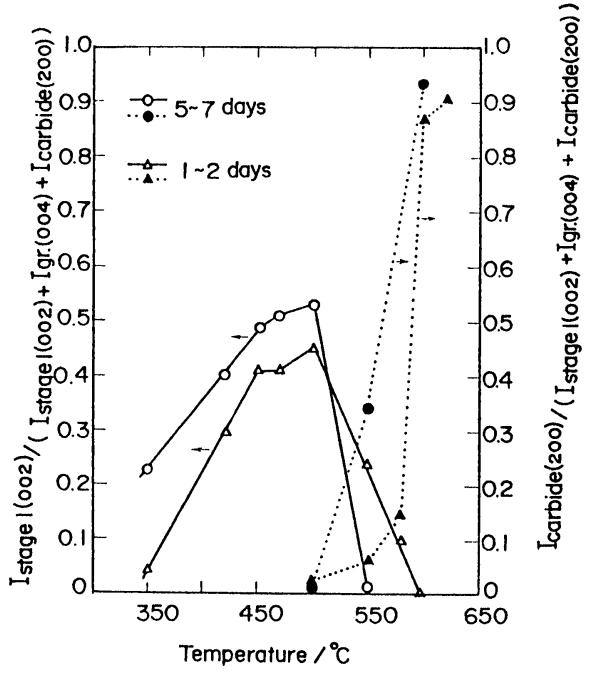

Fig. 5 Plots of relative peak intensity ratio vs. reaction temperature on Sr-Grafoil system.

graphite and the stage 1 Sr-GIC can be obtained. The formation of carbide didn't become predominant below $600^{\circ} \mathrm{C}$. However, even at $470^{\circ} \mathrm{C}$, the formation of carbide was recognized after 2 weeks of the reaction. Thus, it was eventually impossible to obtain a single phase Sr-GIC from Grafoil because the rate of the formation of Sr-GIC was slow and carbide formation was likely to occur after the prolonged reaction period.

\subsection{Preparation of Sr-GICs from artificial graphite}

The stage 1 Sr-GIC was also obtained from an artificial graphite (petroleum coke HTT $2600^{\circ} \mathrm{C}$ ). The appearance was yellow and the X-ray diffraction diagram of the product showed that it was a mixture of graphite and the stage 1 Sr-GIC.

\subsection{Stability of Sr-GICs}

The stage 1 Sr-GIC was found to be fairly stable in the air. For an example, figure 6 shows the change of the X-ray diffraction diagram of the stage 1 Sr-GIC prepared from natural graphite flake. Actually, the sample used here was not the pure stage $1 \mathrm{Sr}$-GIC, but a mixture of stage 1 GIC and unreacted graphite, as seen in Fig. 6(a). It should be noted that even when it was exposed to the air at $120^{\circ} \mathrm{C}$ for 6 days, as shown in Fig. $6(\mathrm{~b})$, the (002) line of stage $1 \mathrm{Sr}$-GIC is clearly seen, although the peak intensity is diminished.

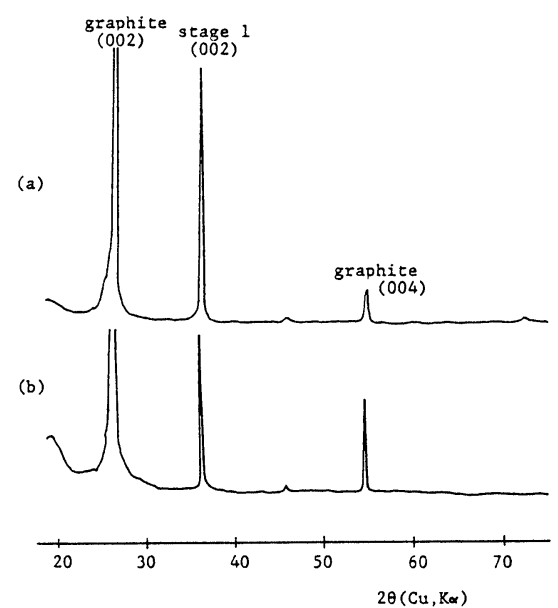

Fig. 6 Change of X-ray diffraction diagrams of stage $1 \mathrm{Sr}-\mathrm{GIC}$ from natural graphite flake. Before, (a), and after, (b), 6 days of exposure to the air at $120^{\circ} \mathrm{C}$.

\section{CONCLUSION}

The identity period and chemical composition of the isolated stage $1 \mathrm{Sr}$-GIC were determined to be $4.95 \AA$ and $\mathrm{SrC}_{6}$, respectively, in accordance with those reported by Guerard et al.

The reaction temperature appropriate for preparing stage $1 \mathrm{Sr}$-GIC from natural graphite flake was determined to be between 460 and $490^{\circ} \mathrm{C}$. The reaction period should be also controlled because the carbide was formed as the reaction period was prolonged. Above $500^{\circ} \mathrm{C}$ carbide formation was pronounced, while below $450^{\circ} \mathrm{C}$ the reaction rate was too slow. On the other hand, when we used Grafoil as the starting graphite material, we could not obtain a homogeneous single phase Sr-GIC.

The stage 1 Sr-GIC was very stable in the air: even after 6 days of exposure to the air at $120^{\circ} \mathrm{C}$, the decomposition rate was very slow and a fairly large part of it remained without decomposition.

\section{Acknowledgement}

The authors are grateful to Mr. Sasagawa of Nippon Kokuen Shoji Co. Ltd. and Tokai Carbon Co. Ltd. for providing graphite samples. 


\section{REFERENCES}

1) D. Guerard and A. Herold, C. R. Acad. Sci. Paris 280, Ser. C, 729 (1975)

2) D. Guerard, M. Chaabouni, P. Lagrange, M. EL. Makrini and A. Herold, Carbon 18, 257 (1980)

3) H. P. Boehm and P. Schlögl, Proceedings of Carbon '82, p. 91 (1982)
4) N. Akuzawa, T. Amemiya and Y. Takahashi, Proceedings of International Symposium on Carbon at Toyohashi, p. 507 (1982)

5) H. L. Huffman, L. B. Ebert and D. R. Mills, Proceedings of the 12th North American Thermal Analysis Society Conference, p. 156 (1983)

\section{学振 117 委員会第 183 回会議}

学振 117 委員会第 182 回会議が昭和 60 年 2 月 27 日(水), 28日(木)に神田学士会館に扔いて開催された。各分科会 には下記の資料が提出され，活発な討論がなされた。 117-183-A-1 炭素質メソフェーズのモデルー縮合 多環芳香族化合物の液晶化（九工試）中溝 実ほか 117-183-A-2 K-GIC の合成とその反応性 （東京高専）阿久沢 昇ほ力 117-183-A-3 ピッチとその複合材のレオロジー

（豊橋技科大）稲垣道夫ほか

117-183-B-1 Electron Transport in GIC's with $\mathrm{ICl}$ （日大理工）Y. Ohtaほ加

117-183-B-2 炭素繊維の微細組織の走查電子顕微鏡 に上る観察法（武蔵工大）菱山幸有ほか 117-183-B-3 ラジアルタイプメソフェーズピッチ系 炭素瀻維の微細構造之磁気抵抗

（武蔵工大）菱山幸有ほか
117-183-B-4 炭素繊維の反磁性

（日大理工）松原恵子ほか

117-183-C-1 高密度炭素材料及び炭素一七ラミック ス複合焼結体の熱的性質と炭素一七ラミックス複合焼 結体の金属溶湯摚拌用翼としての応用

（九工試）宮崎憲治ほ加

117-183-C-2 実用炉環境下に打ける原子炉級黒鉛材 料の照射挙動（原研）松尾秀人ほか

117-183-C-3 天然黒鉛をホストとする $\mathrm{CuCl}_{2}$ 層間化 合物の合成拉よび $\mathrm{CuCl}_{2}$ 層間化合物と銅とからなる成 形体について

（富士カーボン）大平雅彦ほか 117-183-C-4 流動する金属超微粒体によって得られ る気相成長炭素繊維の構造

（信州大工）遠藤守信ほか 